\title{
FOOD SECURITY IN BANGLADESH: PRESENT STATUS AND TREND
}

\author{
M. E. A. Begum ${ }^{1}$, M. I. Hossain ${ }^{2}$ and Luc D'Haese ${ }^{3}$ \\ Bangladesh Agricultural Research Institute, Joydebpur, Gazipur, Bangladesh
}

\begin{abstract}
The study was is an attempt that offers better understanding the overall trend and pattern of food consumption and micro-nutrient intake using secondary data. The study revealed that total dietary energy consumption was $2230 \mathrm{kcal} / \mathrm{capita} /$ day which was higher than the total energy requirements of $2225 \mathrm{kcal} / \mathrm{capita} /$ day in 2003-2005. The shares of energy from protein $(8.61 \%)$ and from fat $(10.90 \%)$ were lower than $12 \%$ and $20 \%$ respectively, although upward trends for dietary fat and protein consumption were observed in between 1969-1971 and 2003-2005. The prevalence of child malnutrition declined in between 1992 and 2006. The results indicate that Bangladesh is not currently food secure in the sense of share of the total energy coming from protein and fat.
\end{abstract}

Key Words: Nutrition security, Food intake, Dietary energy requirement, Micro-nutrient

\section{INTRODUCTION}

Food security encompasses three elements: availability, accessibility and utilization (USAID, 1996). Food availability refers to the physical presence of food at various levels from household to national level, be that from own production or through markets (FANTA, 2006). Food access refers to the ability to obtain an appropriate and nutritious diet and is in particular linked to resources at the household level. Food utilization refers to the proper use of food, which includes the existence of proper food processing and storage practices, adequate knowledge and application of nutrition and child care, and adequate health and sanitation services (FANTA, 2006).

Food security is multi-dimensional having interrelationships among these three elements. There is a fourth exogenous dimension that has significant interface with food security, i.e. the nature. The natural disasters affect all the three dimensions of food security. Food availability by itself does not ensure adequate access to food, although it is a necessary precondition for access to food. If people have access to livelihood, they would have access to food and nutrition. Poor physical access to food leads to poor consumption and poor

\footnotetext{
${ }^{1}$ Agricultural Economics Division, Bangladesh Agricultural Research Institute (BARI) Joydebpur, Gazipur, Bangladesh

2 Department of Agribusiness and Marketing, Bangladesh Agricultural University, Mymensingh-2202, Bangladesh

${ }^{3}$ Department of Bio-Engineering, Antwerp University, Antwerp, Belgium

* Correspondence author (Email: esmatbau@yahoo.com)
} 
nutrition. The levels of food consumption depend mainly upon food availability and food access. Food production is linked to livelihood access and food consumption. Livelihood access in turn influences the demand for food and better prices and production thereof. Better livelihood access also leads to improved living standard, better education, better knowledge on health etc. The interrelationships among food availability, access, utilization and nature are shown in the Fig. 1.

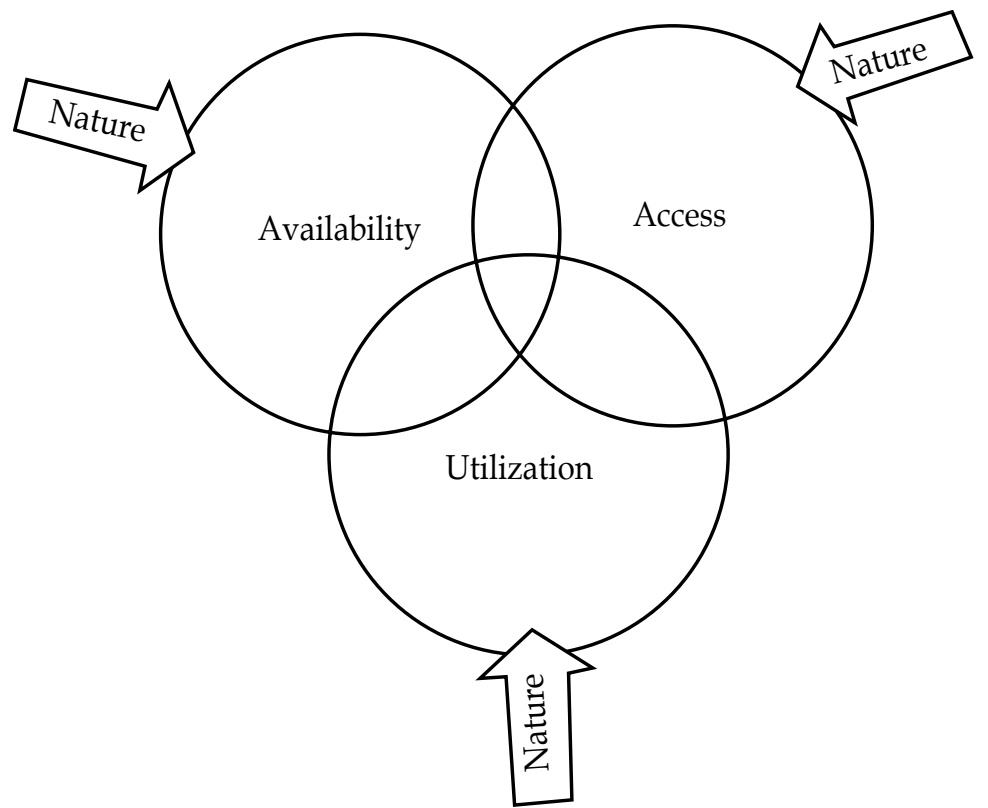

Fig. 1. The interrelationship among major components of food security (Partially adopted from Dash, 2005)

Although food grain production has more than doubled since independence in 1971, food insecurity both in national and household level remains a matter of concern for the government. About half of the population can not reach the minimum dietary energy requirement (2122 kcal/capita/day) and one quarter of them subsist in extreme shortage of energy consuming less than $1800 \mathrm{kcal} /$ capita/day (GOB, 2000). Apart from the prevailing deficit in total calorie intake, the normal diet of Bangladeshi people is seriously imbalanced, with inadequate shares of fat, oil and protein (GOB, 2000). Women and children are especially vulnerable due to their limited access to food. This dietary imbalance reflects insufficient domestic production of non-cereal foods (pulses, oilseeds, fruits, meat, milk and eggs), low incomes, food preferences and lack of nutrition knowledge.

The dietary balance is particularly important for young children and adolescent girls, who need nutrients for growth, and for pregnant and lactating women. Nutrition, comprising adequate quality and quantity of food intake and reduction of illness is a basic human right and is an essential input for economic development in Bangladesh. Therefore, ensuring sufficient consumption of macro-nutrients (calories, protein, and fats and oils) is at the heart of food security policy. Efforts at increasing food production, availability and access have 
aimed largely at ultimately increasing cereals and non-cereals calories consumed. Past studies suggest that consumed cereal diets meet nutritional demand in terms of energy needs as well as protein requirements (Sukhatme, 1978 and Gopalan, 1968). Indeed, many vitamins and mineral deficiencies would also be reduced if sufficient calories were consumed (Greer and Thorbecke, 1986). The cereals, particularly rice (currently over 470 $\mathrm{g} /$ person/day) in the diet is so high that their contribution to total dietary energy nears about $75-80 \%$ in Bangladesh (Yusuf, 1997). And over the period, the supply of cereals (mainly rice) increased (despite consumption of cereals even in excess of the set amount of $454 \mathrm{gm} /$ person/day (Hossain at el., 2005), but the country suffers sufficient consumption of balanced food which indicates the inadequateness of diet from nutritional point of view. Also, due to the low yield of production and lack of access to food turn the country to the problem of balanced diet alone with sufficient amount of calorie intake from cereals and non-cereals. Therefore, insufficient calories, energy and protein intake which can be supplemented by cereals and non-cereals intake are also a problem in Bangladesh.

Based on the above mentioned situation, the objectives of this paper are:

i. to examine the present status and trends of nutrition security of food in Bangladesh; and

ii. to conclude policy implications in relation to improvement of nutritional security at the national level.

\section{METHODOLOGY}

The study was achieved through the use of secondary data. The necessary data were collected from the Bangladesh Bureau of Statistics (BBS), World Bank, Household Income and Expenditure Survey (HIES), Child Nutrition Survey of Bangladesh, FAOSTAT and other published and non-published sources. These were also used to analyze the historical consumption and nutrition of food. A descriptive analysis was followed to understand the overall trend and pattern of food consumption and energy intake using available secondary data. Analysis also helps in determining the indicators for achieving nutritional food intake and thereby identifying the appropriate interventions at the national level to improve nutritional security.

\section{RESULTS AND DISCUSSION}

\section{Trend and pattern of food intake: adequacy of food consumption}

The level of consumption of different food items has been shown in Table 1. The consumption of rice in rural areas reached a level much higher than the minimum requirement; there is a marginal deficit for potatoes, vegetables and fish; and substantial deficits for pulses, oils, meat and eggs that are major sources of protein and micro-nutrients. The consumption of rice in urban areas was lower compared to rural areas while the consumption of other food items was higher. It reveals from the composition of the diet that the quality of the food basket is better for urban areas compared to rural areas. 


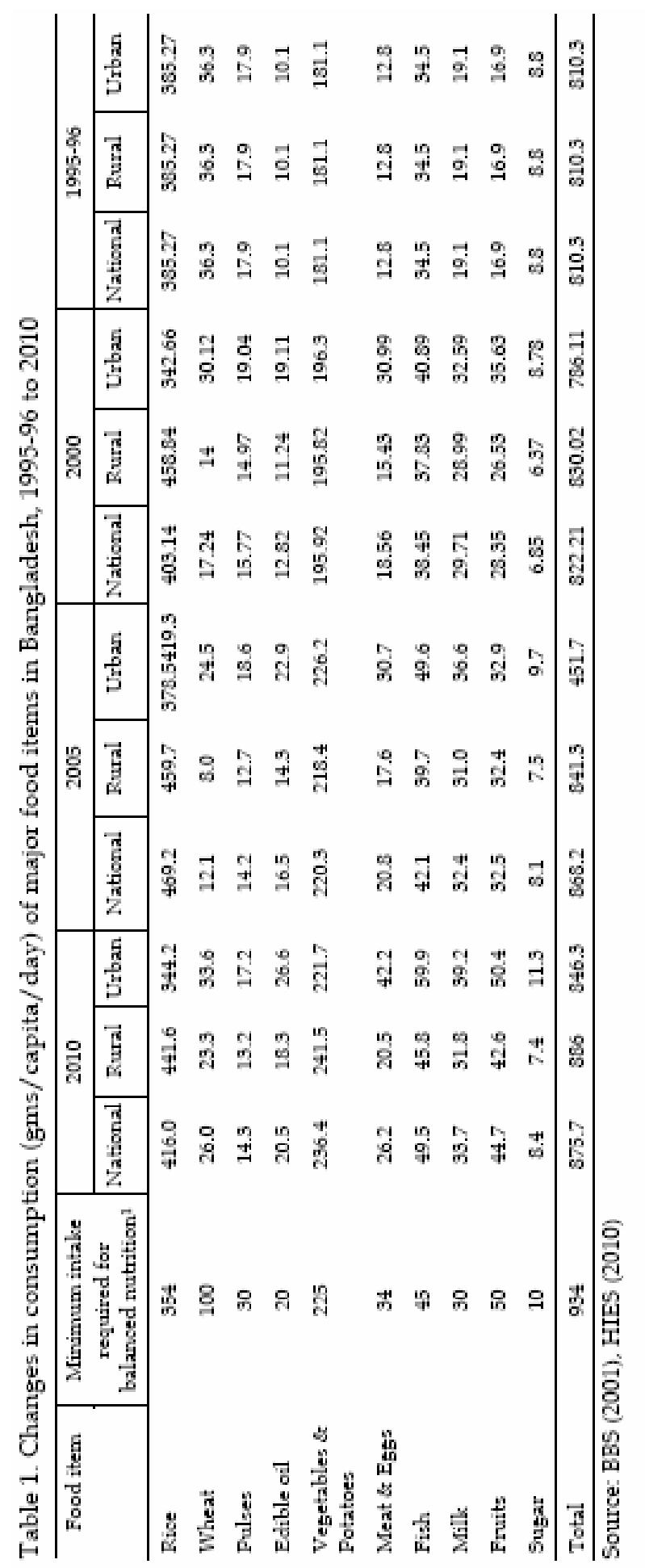


For both rural and urban areas, the total consumption of food has declined in 2010. The total intake was about $11 \%$ and $15 \%$ lower in rural and urban areas respectively; and for the national level, it was $12 \%$ lower than the minimum requirement (Table 1). There has been declining trend in the wheat consumption and increasing trend in the consumption of fruits, fish, and meat and eggs at the national level which indicates the improvement of balance food intake in the national level.

It is also observed from the Table 1 that there has been a declining trend of rice consumption for the urban areas during the last decade which is contrast to the substantial increase in rice production in same years. That is why it could be said that the urban area has reached the threshold consumption level. Two reasons are assumed behind this: on the one hand, because of one hand, after the threshold level of income, when people can afford to have a diversified diet needed for balanced nutrition, the per capita consumption of staple food starts declining, but the poor are still spending their additional income on rice. On the other hand, it could be argued that the decline in rice consumption is a reflection of upward trend in the proportion of slum population due to rapid rural-urban migration resulted in higher pressure for expenditures which could reduce the purchasing power of staple food.

\section{Calorie and protein intake}

The long-term trend in the calorie, protein and fat intake have been shown in Fig. 2. It reveals upward trend for dietary fat consumption in between 1969-1971 and 2003-2005, fat intake increased from $15 \mathrm{gms} /$ capita/day to $25 \mathrm{gms} / \mathrm{capita} /$ day and decreased in both for the calorie and protein intake until 1995-1997, since then they increased. During the period 2003-2005, the energy intake was 2,230 kcal per capita per day and the protein intake was 48 gms per capita per day (FAOSTAT, 2007).

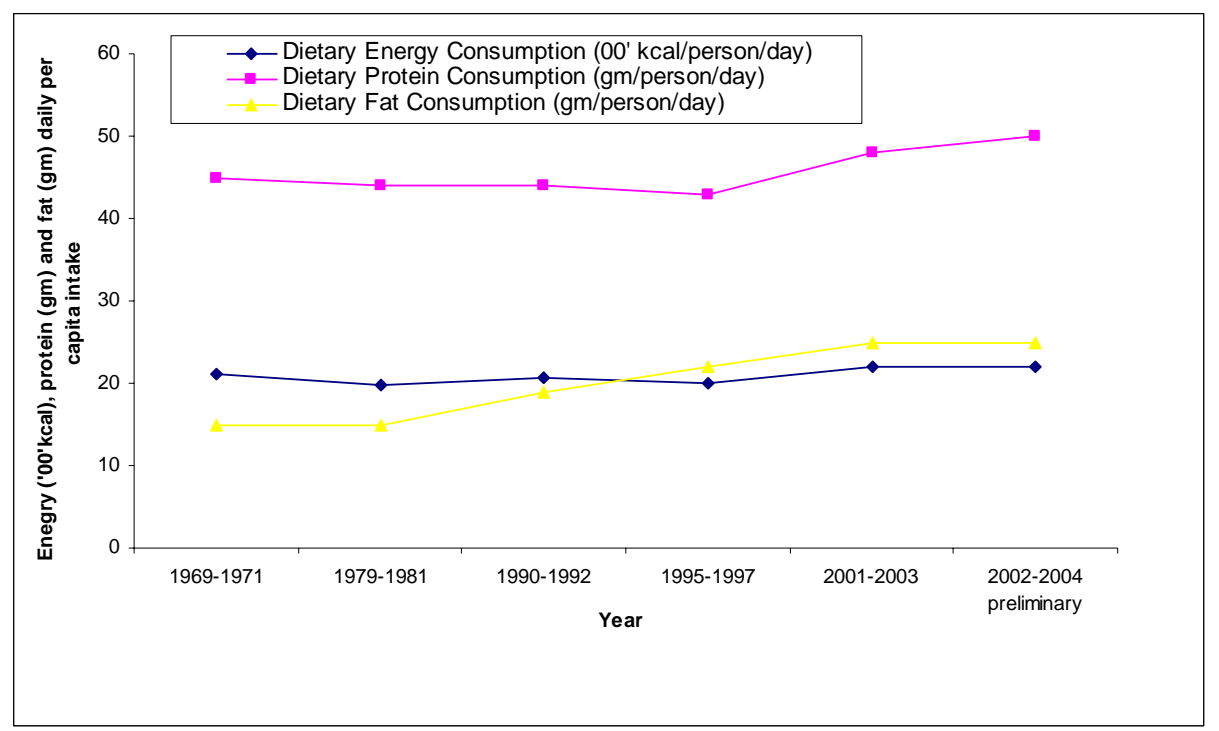

Fig. 2. Trends in energy intake, protein and fat, 1969 to 2004

Source: FAOSTAT (2010) 
According to the Food and Agricultural Organization, the minimum dietary requirement in terms of energy is $1780 \mathrm{kcal} / \mathrm{capita} /$ day and the real availability is 2230 in Bangladesh (Table 2). To meet the food security, at least $25 \%$ more food in terms of energy should be avail for the Bangladeshi people. So, the total energy requirement is the sum of minimum requirement and $25 \%$ of the minimum requirement which is $2225 \mathrm{kcal} /$ capita/day, is lower than total dietary consumption.

Table 2. Level of dietary energy, protein and fat consumption in Bangladesh

\begin{tabular}{c|c|c|c}
\hline Year & $\begin{array}{c}\text { Energy consumption } \\
\text { (kcal/capita/day) }\end{array}$ & $\begin{array}{c}\text { Protein consumption } \\
\text { (gm/capita/day) }\end{array}$ & $\begin{array}{c}\text { Fat consumption } \\
\text { (gm/capita/day) }\end{array}$ \\
\hline $1990-92$ & 2010 & $43(8.56)$ & $18(8.06)$ \\
$1995-97$ & 1960 & $42(8.57)$ & $21(9.64)$ \\
$2002-2004$ & 2324.52 & $50(8.6)$ & $25(9.67)$ \\
$2003-2005$ & 2230 & $48(8.61)$ & $27(10.90)$ \\
\hline
\end{tabular}

Source: FAOSTAT (2010). Figures parenthesis indicate the percentage share of energy

Note: Share of energy from protein: $50 * 4 \mathrm{kcal}=200 \mathrm{kcal} ;(200 / 2324.52) * 100 \%=8.60 \%$, Share of energy from fat: $25^{*} 9 \mathrm{kcal}=225 ;(225 / 2324.52) * 100 \%=9.67 \%$

On the other hand, at least $12 \%$ energy should come from protein and $20 \%$ energy should come from fat. The share of energy from protein $(8.61 \%)$ and from fat $(10.90 \%)$ is lower than $12 \%$ and $20 \%$ respectively. Therefore, it may be concluded that Bangladesh is apparently just food secured in terms of total energy, but still it is not food secured in terms of share of the total energy coming from protein and fat.

\section{Changes in nutritional status}

Prevalence of malnutrition, particularly child malnutrition, though on a downward trend, is still at high level. About $40 \%$ of all children between 6 and 71 months are underweight or low weight for age, while more than $30 \%$ of them are stunted or low height for age (Table 3). Percentage of rural malnourished children was much higher than that of urban areas. Nearly $20 \%$ of the rural children are severely stunted and about $13 \%$ severely underweight.

Table 3. Rural-urban difference in child (6-71 months) malnutrition (percent), 2000

\begin{tabular}{l|c|c|c}
\hline Indicators & Area & Severe & Moderate \\
\hline \multirow{2}{*}{ Wasting } & Rural & 1.0 & 10.9 \\
& Urban & 1.8 & 9.0 \\
& National & 1.1 & 10.6 \\
\hline \multirow{2}{*}{ Stunting } & Rural & 19.7 & 31.0 \\
& Urban & 15.0 & 23.3 \\
& National & 19.0 & 29.8 \\
\hline \multirow{2}{*}{ Underweight } & Rural & 13.2 & 39.6 \\
& Urban & 9.6 & 32.6 \\
& National & 12.6 & 38.5 \\
\hline
\end{tabular}

Source: Child Nutrition Survey of Bangladesh (2000) 
The downward trends in stunting and underweight indicate that there has been considerable improvement in child malnutrition in Bangladesh (Fig. 3). The prevalence of stunting, wasting and underweight has declined between 1992 and 2004 at a rate of 3.1, 2.6 and $2.7 \%$ respectively per annum. The trend of wasting indicate shortage of food while the faster decline of stunting and underweight indicate improved food security situation in recent years.

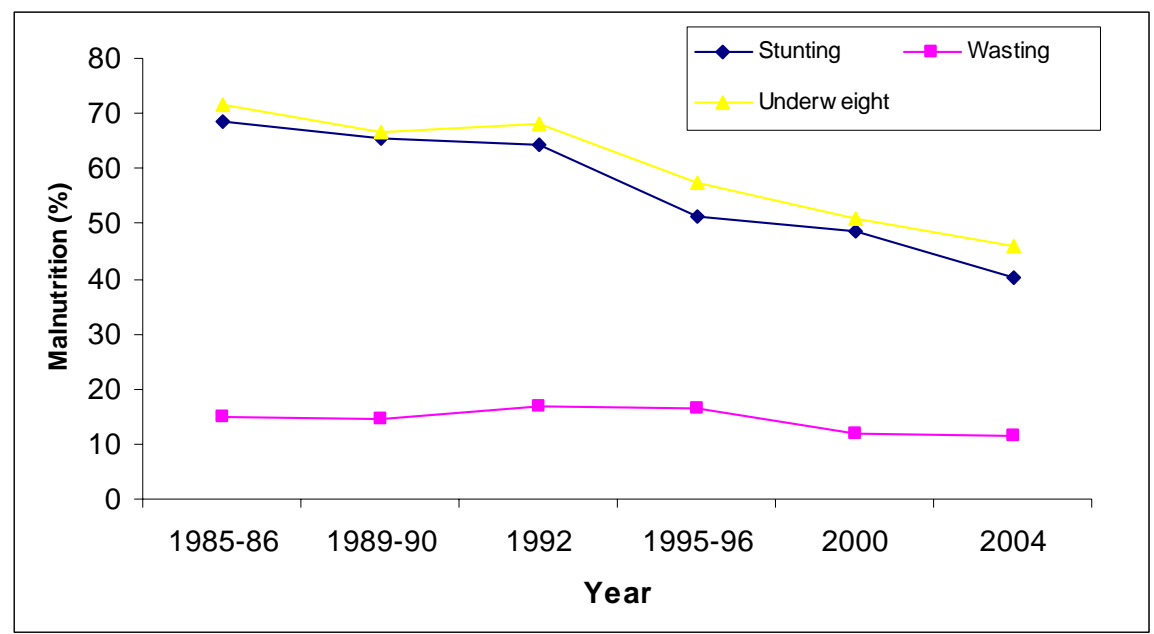

Fig. 3. Trends in child malnutrition in Bangladesh, 1985 to 2000

Source: Child Nutrition Survey of Bangladesh, 2000 and FAOSTAT, 2010

From the Table 4, it is observed that the prevalence of undernourishment has increased in 1995-1997 but decreased in 2000-2002 and it was the same in 2002-2004. The life expectancy has increased remarkably from 55 years in 1990-1992 to 63 years in 2004. On the other hand, children mortality under five and infant mortality decreased from 144 and 96 in 1990-1992 to 77 and 56 per 1000 in 2004 respectively. Therefore, it could be argued that health status of people in Bangladesh has gradually improved.

Table 4. Changes in selected food security indicators 1990-2002

\begin{tabular}{ll|c|c|c|c}
\hline \multicolumn{1}{c|}{ Indicators } & & $1990-92$ & $1995-97$ & $2000-02$ & $2002-04$ \\
\hline Prevalence of undernourishment & (Per cent) & 35 & 40 & 30 & 30 \\
Number of undernourished & (Million) & 39.2 & 50.4 & 42.5 & 44.0 \\
Children mortality rate under five years & (per 1,000) & 144 & 116 & 82 & $77^{*}$ \\
Infant mortality rate & (per 1,000) & 96 & 75 & 54 & $56^{*}$ \\
Life expectancy & (Years) & 55 & 60 & 62 & $63^{*}$ \\
\hline
\end{tabular}

Source: World Bank (2005a), *period, 2004

\section{CONCLUSIONS}

Rice is considered as the main food for Bangladeshi people. The consumption of rice for urban areas was lower compared to rural areas while the consumption of other food items 
was higher. It indicates that the diet in terms of quality of the food basket was better for urban areas compared to rural areas. In 1995-1997, both the calorie and protein intake had decreased, but in 2003-2005 it increased, and upward trend for dietary fat consumption in between 1969-1971 and 2003-2005. The total energy requirement (2225 kcal/capita/day) is lower than total dietary consumption (2230 kcal/capita/day). The shares of energy from protein $(8.61 \%)$ and fat $(10.90 \%)$ are lower than $12 \%$ and $20 \%$ respectively. The downward trends in stunting and underweight indicate that there has been a considerable improvement in child malnutrition, but it is still at high level in Bangladesh. The results indicate that despite the improvement of the food security situation at the national level through improvement of nutritional status, still Bangladesh is not food secure in the sense of share of the total energy coming from protein and fat.

\section{Policy recommendations}

The study recommends for improving purchasing power and socio-economic status of the people and for strengthening formal and non-formal education programs to popularize the idea of balanced food and take steps for communication of dietary guidelines on balanced food in the mass media.

This study is based on national aggregate data. The household survey data may give more insight into the nutritional food security problem of Bangladesh. So, the analysis can be extended by using household survey data for the food balance sheet and disaggregated household food consumption.

\section{ACKNOWLEDGEMENT}

This article is derived from first author's MA thesis submitted for fulfilling MA in Development Evaluation and Management, Institute of Development Policy and Management (IOB), University of Antwerp, Belgium. The authors are grateful to the Belgian Ministry for Development Cooperation and the Bangladesh Agricultural Research Institute, Joydebpur, Gazipur, Bangladesh for providing research scholarship and granting a study leave to pursuing higher study respectively.

\section{REFERENCES}

BBS. 2001. The Statistical Yearbook of Bangladesh, Bangladesh Bureau of Statistics, Planning Division, Ministry of Planning, Government of the Peoples' Republic of Bangladesh, Dhaka, Bangladesh.

BBS. 2005. The Statistical Yearbook of Bangladesh, Bangladesh Bureau of Statistics, Planning Division, Ministry of Planning, Government of the Peoples' Republic of Bangladesh, Dhaka, Bangladesh.

Child Nutrition Survey of Bangladesh. 2000. Bangladesh Bureau of Statistics, Ministry of Planning, Government of the Peoples' Republic of Bangladesh, Dhaka, Bangladesh.

Dash, B. P. 2005. Regional Food Security Experience: Lessons Learnt from India and Timor Leste, Papers presented in national the workshop, Ministry of Food and Disaster Management, Government of the People's Republic of Bangladesh and World Food Program, IDB Bhaban, Agargaon, Dhaka. 
FAO. 2003. The State of Food Insecurity in the World, Monitoring Progress Towards the World Summit and Millennium Development Goals, Rome, Italy.

FAO. 2006. The State of Food Insecurity in the World, Eradicating World Hunger-Taking Stock Ten Years after the World Food Summit, Rome, Italy.

FAOSTAT. 2010. Food Balance Sheet, FAOSTAT data, Rome, Italy. http://faostat.fao.org/site/502/ DesktopDefault.aspx?PageID=502 (Last consulted: June, 2010)

FANTA. 2006. Food and Nutrition Technical Assistance, Food Security, http://www.fantaproject. org/focus/foodsecurity.shtml (Last consulted: July 11, 2007)

GOB. 1999. Bangladesh Economic Review, Ministry of Finance, Dhaka, Bangladesh.

GOB. 2000. Report of the Task Force on Comprehensive Food Security Policy for Bangladesh, Government of the Peoples' Republic of Bangladesh, Bangladesh.

Gopalan, C. 1968. Leucine and Pellagra, Nutrition Reviews, 26: 323-326.

Greer, J. and Thorbecke, E. 1986. A Methodology for Measuring Food Poverty Applied to Kenya, Journal of Development Economics, 24: 59-74.

Harun, K.M., and Islam A. 2005. Setting A Standard Cereal Intake for Balanced Nutrition in Bangladesh, Papers presented in the national workshop, Ministry of Food and Disaster Management, Government of the People's Republic of Bangladesh and World Food Program, IDB Bhaban, Agargaon, Dhaka.

HIES. 2010. Report of the Household Income and Expenditure Survey, Bangladesh Bureau of Statistics, Ministry of Planning, Government of the Peoples' Republic of Bangladesh, Dhaka, Bangladesh.

Hossain, M., Naher, F. and Shahabuddin, Q. 2005. Food Security and Nutrition in Bangladesh: Progress and Determinants, Journal of Agricultural and Development Economics, 2(2): 103-132.

Sukhatme, P.V. 1978. Assessment of Adequacy of Diets at Different Income Levels, Economic and Political Weekly, 12: 31-32.

USAID. 1996. Annual Food Assistance Report (PN-ABZ-119). United State Agency for International Development, Washington, DC.

USDA. 1995. Food and Consumer Service Office of Analysis and Evaluation, Conference on food Security Measurement and Research: Washington, DC.

World Bank. 2005a. World Development Indicator (WDI), Washington, DC.

Yusuf, H. K. M. 1997. Nutrition situation in Bangladesh, In: Sustained Food Security Mission Report, FAO, Rome. 